\title{
Prophylactic, nutritional, seasonal and pathological consideration of Ahara as per
}

\author{
Ayurveda \\ Available online at www.ijistweb.com \\ REVIEW ARTICLE \\ Rahul Kumar Gupta*1 ${ }^{\mathbf{1}}$, Dinesh Malviya ${ }^{2}$, Pradeep Soni ${ }^{3}$, Jitendra Shrivastava $^{4}$, Pawan Rajput ${ }^{5}$ \\ ${ }^{1}$ Dept of Dravyaguna, Govt. Ayurved College, Gwalior, (M.P.) India. \\ ${ }^{2}$ Dept of Sharir Kriya, Govt. Ayurved College, Gwalior, (M.P.) India. \\ ${ }^{3}$ Dept of Rachana Sharir, Govt. Ayurved College, Gwalior, (M.P.) India. \\ ${ }^{4}$ Dept. of Panchakarma, Govt. Ayurved College, Gwalior, (M.P.) India. \\ ${ }^{5}$ Dept. of Rasashastra \& Bhaishajya Kalpana, Govt. Ayurved College, Gwalior, (M.P.) India. \\ *Corresponding Author's E-mail: drrahulkgupta17@gmail.com
}

\begin{abstract}
The dietary pattern of human being aimed to maintain good health which came in practice after lot of evaluation including trial and error based consideration. The different culture of human civilization offered number of food preparations which help to promote health through different nutritional value. The traditional science of India Ayurveda also aimed to promote and preserve the health and longevity. The various conceptual belongings of ayurveda play vital role towards achieving this goal and dietary consideration is one of them. Ayurveda believe that the dietary consideration as per desha, kala and prakrirti, etc. not only help to promote health but also cure the diseases. Ahara sometimes also used as a curative measure therefore specific diet pattern recommended as prophylactic approach for the prevention of some common diseases. Good quality food stuffs improve memory, energy, digestive power, intellectual and ojas. This article summarized health benefits of food and various rules of ayurveda related to dietary consideration.
\end{abstract}

Keywords: Ayurveda, Ahara, Diet, Nutrition, Prophylactic nutrition.

\section{Introduction}

Ayurveda is the science of healthcare management which emphasized prevention of disease rather than treatment. Ayurveda described remarkable importance of ahara towards the maintenance of good health since it will keep dhatu and doshas in healthy state which are the prime elements of healthy status. Ayurveda believe that complexion, voice, longevity, happiness, strength; growth and intelligence depend upon the types of food materials which an individual consumed.

Certain food stuffs such as; rice, green gram, milk and honey etc. are considered as Sada pathyakara means these items offers beneficial effects most of the time. These food items enhance appetite, promote growth, generate essential heat, boost tissue repairing process, and eliminate waste products from body and potentate inherent immunity.
Acharya charaka has mentioned that rice, green gram, gooseberry, milk, ghee, grains and honey, etc. should be adopted in routine diet regimen. Ayurveda believe that general dietary regimen should contain composite of Pancha mahabhutas elements to meet the need of composite body structure. Ayurveda also emphasized that diet should having essential rasas such as; sour, salt, bitter, astringent and pungent since these rasa offers specific nourishment of body.

As per ayurveda following aspects need to be considered for achieving maximum health benefits of ahara:

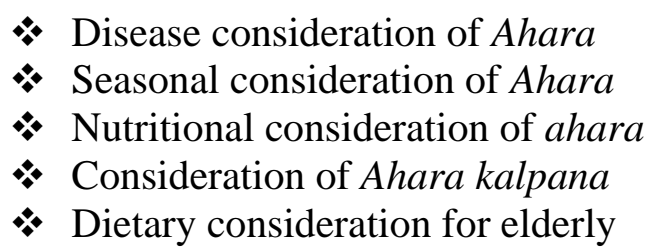

* Disease consideration of Ahara

* Seasonal consideration of Ahara

* Nutritional consideration of ahara

* Dietary consideration for elderly 


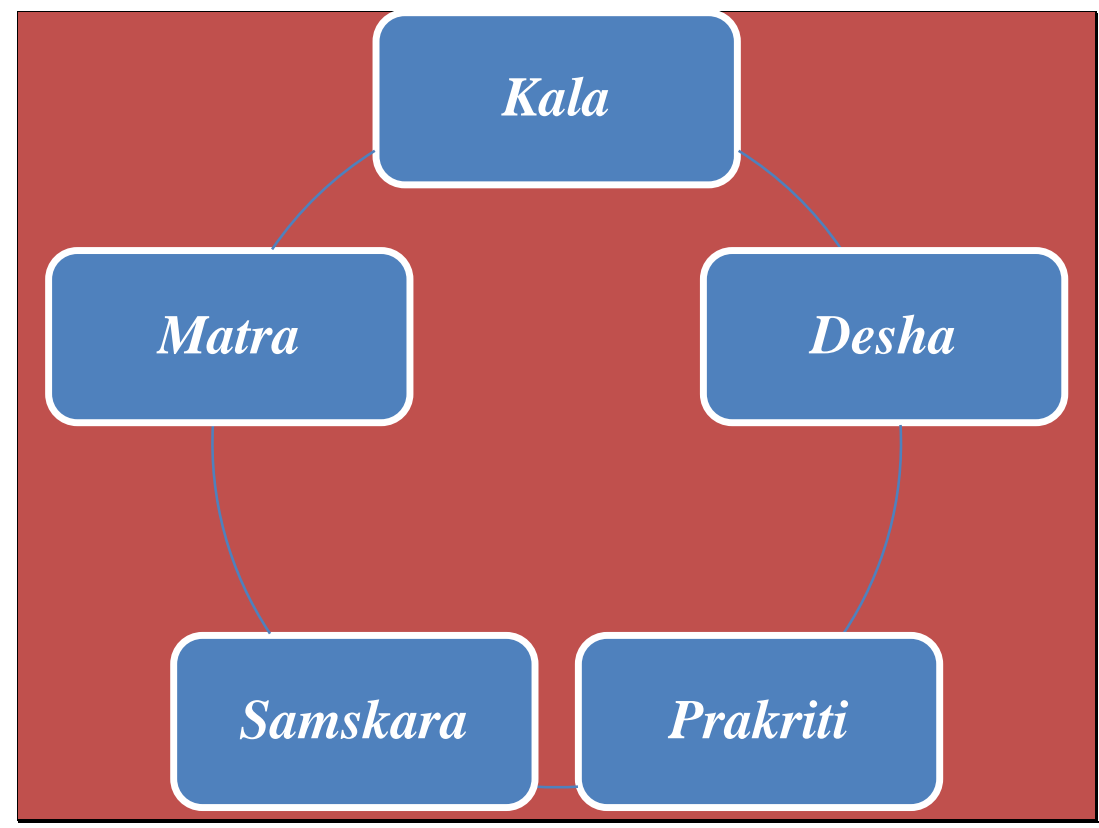

Figure 1: Various aspects which affect quality and health benefits of ahara

\section{Disease consideration of Ahara:}

Ayurveda described various types of dietary regimen as per the predominance disease conditions as mentioned in Table 1.

Table 1: Various types of dietary regimen as per the predominance disease conditions

\begin{tabular}{|c|c|c|c|}
\hline S. No. & $\begin{array}{l}\text { Pathological } \\
\text { condition }\end{array}$ & Diet suggested & Diet restricted \\
\hline 1 & Madhumeha & Barley, old wheat and green gram. & $\begin{array}{l}\text { Excessive milk and sugar products } \\
\text { etc }\end{array}$ \\
\hline 2 & Vata vyadhi & Warm food and milk products etc. & Dry, cold food and fasting. \\
\hline 3 & Kushta & Wheat green gram and ghee etc. & Uncooked food, salty substances. \\
\hline 4 & Arsha & Wheat, buttermilk and red rice etc. & $\begin{array}{l}\text { Dry food articles, fish and black } \\
\text { gram. }\end{array}$ \\
\hline 5 & Amlapitta & $\begin{array}{l}\text { Old rice, barley, sugar and honey } \\
\text { etc. }\end{array}$ & Saline, pungent, sour food and curd. \\
\hline 6 & Vrana & Food which is not too cold. & Saline, sour, hot and heavy food. \\
\hline 7 & Aamavata & $\begin{array}{l}\text { Buttermilk, old rice, castor oil and } \\
\text { drumstick. }\end{array}$ & Curd, fish and Virudha Ahara. \\
\hline 8 & Medoroga & $\begin{array}{l}\text { Green gram, dry food, honey and } \\
\text { fasting etc. }\end{array}$ & Milk, fatty food, meat and fish. \\
\hline
\end{tabular}

\section{Seasonal consideration of Ahara}

Ayurveda also suggested that the ahara should be consumed as per the seasonal variation to get maximum beneficial effects of food stuffs:

* It is believed that in winter season the digestive power increased hence heavy food stuffs may be consumed if required. In this season cold food stuff should be avoided.
* During Vasanta Kala kapha gets aggravated therefore light and digestable food should be consumed while heavy unctuous and sweet material should be avoided.

* During grishma kala it is suggested to take cold, liquid and unctuous diet due to the hot weather condition, however salty, sour and hot foods stuffs should be avoided during summer season. 
In Varsha Ritu old barley, wheat, sali rice, meat and vegetable soup recommended maintaining digestive power. The unhygienic food or outside from home not recommended.

* In sarat ritu it is recommended to consume sweet, light, bitter and cold food stuff to alleviate the vitiated pitta.

\section{Nutritional consideration of ahara}

Ayurveda also believe that various food stuffs offer specific nutritional value therefore one should consume ahara as per his/her needs. Table 2 described nutritional benefits of various food items:

Table 2: Nutritional value of various food items as per Ayurveda

\begin{tabular}{ccl} 
S. No. & Name & \multicolumn{1}{c}{ Nutritional Benefits } \\
$\mathbf{1}$ & Mudga & Pacify vitiated kapha, pitta, boost drishtiprasadana. \\
\hline $\mathbf{2}$ & Masha & Laxative and aphrodisiac. \\
\hline $\mathbf{3}$ & Sali, Shashtika & Pacify vitiated biohumors and maintains body composition. \\
\hline $\mathbf{4}$ & Godhuma & Restorative, aphrodisiac and invigorating. \\
\hline $\mathbf{5}$ & Mamsa & $\begin{array}{l}\text { Nourishing body, help to build composite body and enhance } \\
\text { physical strength. }\end{array}$ \\
\hline $\mathbf{6}$ & Matsya & $\begin{array}{l}\text { Promoting strength, unctuous, aphrodisiac and boost } \\
\text { intellectual. }\end{array}$ \\
\hline $\mathbf{7}$ & Vatada & $\begin{array}{l}\text { Promoting mental growth nourishes dhatu and aphrodisiac } \\
\text { effect. }\end{array}$ \\
\hline $\mathbf{8}$ & Hingu & Demulcent, laxative, relieves colic pain and boost digestion. \\
\hline $\mathbf{1 0}$ & Maricha & Stimulant, expectorant, decongestant and boost agni. \\
\hline $\mathbf{1 1}$ & Haridra & $\begin{array}{l}\text { Anti-inflammatory, antiseptic, useful for asthma and chronic } \\
\text { cough. }\end{array}$ \\
\hline $\mathbf{1 2}$ & Dadhi & Appetizer, digestive, promoting growth and useful in dysuria. \\
\hline
\end{tabular}

\section{Consideration of Ahara kalpana:}

Ahara kalpana play vital role towards the properties of various food stuffs, the similar food if prepared by different manner then it possess different properties therefore it is very important to understand properties of common food preparations which are as follows:

\section{Ahara kalpana and its property:}

$\begin{array}{ll}\text { * Manda } & \text { Digestive } \\ \text { * Peya } & \text { Nourishes the tissues } \\ \text { * Vilepi } & \text { Diuretic } \\ \text { * Yavagu } & \text { Strengthening } \\ \text { * Krishara } & \text { Supplements }\end{array}$

\section{Dietary consideration for elderly:}

The diet regimens for elderly persons differ from the younger one due to the diminished metabolic activity. Elderly require fewer quantities of food since metabolic rate slows down and the activity levels decrease. Cereals, vegetables, whole pulses and fruits should be preferred over heavy diet. Spicy, salty, hot and uncooked foods are avoided for elderly person. Excessive use of oil and fat should also be avoided however pulses, milk and milk products may be consumed as a source of protein for elderly person. Fruits and fruits juices, soup and vegetables which are rich in vitamins and easily digestible should be incorporated in their routine dietary regimen.

\section{Conclusion}

Ayurveda suggested that diet should be consumed as per the individual constitution depending upon power of gastric fire and it should be consumed at proper time with relax physical and mental status. The virudha-ahara may results pathological initiation and disease progression may take places. Ayurveda strongly recommended that to live healthy one should follow dietic rules. Ayurveda believe that proper diet not only promote positive health but also cure of diseases. Consumption of compatible 
food in proper quantity contributed towards strength, vigor, complexion and immunity.

\section{Acknowledgement}

The authors are thankful to IJIST Journal for publishing their article.

\section{Conflicts of Interest}

The author declares that there are no conflicts of interest.

\section{References}

1. Agnivesha. Charaka samhita. Commentary by Chakrapanidatta. Hindi commentary by kashinath shastry. 8th Edition. Varanasi: Chaukambha Sanskrit Samsthana; 2004. Sutra sthana, 25th chapter, verse 45, 324.

2. Acharya Kashyapa. Kashyapa samhita. Edited by P.V.Tewari.1st Edition. Varanasi: Chaukambha Vishwabharati; 1996. Khila sthana, 4th chapter, verses 4-6, 468.

3. Acharya sushrutha. Sushrutha samhita. Nibhandasangraha commentary of Dalhana acharya and Nyapanjika commentary of Gayadasa. Edited by Yadavaji Trikamaji Acharya. 8th edition. Varanasi: chaukambha Sanskrit samsthana; 2005. Sutra sthana, 46th chapter, verse 3, 214.

4. Yadavji Thrikamji Acharya (2013) (eds.) Charakasamhitha, Sutrasthana 11/35, Chowkambha Surabharathi Prakashan.

5. Agnivesha. Charaka samhita. Commentary by Chakrapanidatta. Hindi commentary by kashinath shastry. 8th Edition. Varanasi: Chaukambha Sanskrit Samsthana; 2004. Sutrasthana, 5th chapter, verse 10, 77.

6. Dr. Shastry V.L.N. kaumarabhrityam. Varanasi: chuakambha orientalia.4th chapter, 84 .

7. Acharya Sharangadhara. Sharangadhara samhita. Annoted with Deepika commentary by Dr. Brahmananda Tripathi. 3rd edition. Varanasi: chaukambha subharati prakashan. Madhyama khanda, 2nd chapter, verse 170, 161.

8. Dr. Shastry V.L.N. kaumarabhrityam. Varanasi: chuakambha orientalia. 4th chapter, 85.

9. Yadavji Thrikamji Acharya (2013) (eds.) Charakasamhitha, Sutrasthana 5/6, Chowkambha Surabharathi Prakashan.

10. Acharya Sharangadhara. Sharangadhara samhita. Annoted with Deepika commentary by Dr.Brahmananda Tripathi. 3rd edition. Varanasi: chaukambha subharati prakashan. Madhyama khanda, 2nd chapter, verse 170, 161. 